\title{
BUSINESS TOURISM CONSULTING: A STUDY OF SEBRAE -AM
}

\author{
Lady Dayane de Oliveira Costaa; \\ Paula Cristina Pereira Rodrigues Chaves ${ }^{b}$
}

\begin{abstract}
The Consultancy services in tourist companies provide knowledge about management and organization of companies, quality of services, and specialization of offer, among other aspects. Through this process, they help make the tourist market more attractive and competitive. The Micro and Small Business Support Service (SEBRAE) operates throughout Brazil, with the aim of promoting competitiveness and sustainable development and fostering entrepreneurship, thereby facilitating the access of small entrepreneurs to business management knowledge, through its Business consulting service. In view of the potential of business consulting, and identifying a facilitator that is accessible in the use of services offered by the institution, this study aimed to understand the system and process used by SEBRAE-AM, in the State of Amazonas, in its consulting services, and to investigate the motivations and expectations of the demand for tourism entrepreneurs, and the consultants' view of this market. We opted for a basic methodology using a qualitative approach, with semi-structured interviews in which three subjects formed part of the intentional sample: manager of the consulting department of SEBRAE-AM, and two consultants working within the area of business activities in tourism. Among other results, the research found that despite the notoriety and the full consultancy work performed by the institution, the demand is still low compared to other business segments, and there are some limitations on the consulting services offered by the institution. This relevance of this research is its potential as a reference model for consulting companies, and it can be used by companies in the consulting area, as well as for the development of new research on this topic.
\end{abstract}

\section{KEYWORDS}

Consulting

Tourism

SEBRAE 


\section{INTRODUCTION}

Aimed at assisting businesses, consulting provides an interactive guidance tool to enhance business management practices, helping companies to make more efficient use of their resources in order to ensure business success.

According to Crocco (2005), consulting is defined as an interactive process, performed by one or more people who are not connected to the problem being analyzed, with the aim of providing executives of the client company with one or more options for change that will result in the decision that best meets the needs of the organization.

The authors Hawkins and Weiss (2004) emphasize the importance of knowledge and applicability of current technologies that enable the resolution of complex problems presented by business organiza-tions.

This research is relevant because it contributes to a vision that transcends the theory, presenting, in a practical and empirical way, several factors that are part of the tourism consulting process developed by the renowned institution SEBRAE - AM. This include: the consultant in SEBRAE system; the structure of the consultancy services provided through the institu-tion; Evaluation of the consultant and the consulting process; The use of tourism consulting in the State of Amazonas; Benefits, limitations and demand in the consulting process in tourist companies and; the tourism market in Amazonas, from the perspective of consulting professionals.

Therefore, the main objectives of this paper are to understand the system and process of the consulting service offered by SEBRAE-AM, and to investigate the motivations and expectations of the demand for tourism entrepreneurs and the consultants' view of this market.

The theoretical background to this work used authors such as Block (1991), Crocco (2005), and Alves et al. (2015), seeking to bring together discussions that can explain the historical context of consultancy, its definitions, profile, types of consultant, and the structure, process and stages of consultancy.

Regarding the methodology, we opted for a basic re-search with a qualitative approach, using semistructured interviews. The sample was selected intentionally and not probabilistically. The subjects chosen were: the manager of the consulting department of SEBRAE-AM, and two consultants who had more experience in the tourism industry and had been working at the institution for a long time.

\section{Consulting AND ITS hISTORI- CAL PROCESS}

The global economy and the rapid development of new technologies, accompanied by the new consumer demands, require a broad and continuously updated knowledge of new forms of business management.

According to Crocco (2005), consulting is defined as an interactive process, performed by one or more people who are not connected to the problem being analyzed, with the aim of providing executives of the client com-pany with one or more options for change that will result in the decision that best meets the needs of the organization.

We looked for a definition of the word consultant; according to Pereira (1999 as cited in Alves, 2015) it means giving or receiving advice, advising and being advised. In other words, the business consultant pro-vides a total or partial analysis of the company (diagnosis), giving guidance on the best alternatives that will meet the needs of the client company.

Consultancy therefore assists in the decisionmaking processes, analyzing the client company's data and showing its executives alternative ways of achieving better results.

Etymologically, the word consultancy comes from the Latin Consultare which means "to receive advice from", which is related to Consulare "to accept advice". It is believed that the practice of 
consultancy may have started in Ancient Greece, where according to Alves et al. (2015), it was performed by priests, men chosen by the Gods, who gave advice to less enlightened people.

Block (1991) states that the essence of consultancy has existed since the dawn of humanity, with leaders, politicians, religious, and ethnic leaders consulting their advisers before making important decisions.

In the current view related to service provision, Alves et al. (2015) explains that consulting emerged in England and the United States in the late nineteenth and early twentieth centuries due to the demand for qualified professionals from the Industrial Revolution. The first consultancy firm was created by Arthur D. Little. After this phase, the US government used the tool to reorganize its military sector after World War II, and the practice later spread to the rest of the world.

However, Block (1991) states that consultancy in its structured form began around the 1900s with Frederick Taylor, at the time of the transition of rail transport and through studies in the production environment. Taylor developed the scientific administration that consisted of applying scientific methods to the complex problems that arose in the management of labor in the rising companies of the time. Overall, Taylor studied organizations using a methodology that divided the pro-duction process into its component parts and, through a structured methodology that helped to identify and resolve the organizational and human efficiency problems of companies.

Shortly after identifying the potential of the methodology used by their precursor, consultants began to ap-ply the diagnostic framework, using their expertise, to address business weaknesses and opportunities.

It is noteworthy that in Brazil, as Oliveira (2009) states, the growth of the segment is identified from the 1960s on, where strong business market growth, led to a need for updated knowledge in business management techniques and methodologies, to deal with the market changes resulting from economic globalization.
It is noteworthy that in Brazil, as Oliveira (2009) states, the growth of the segment is identified from the 1960s on, where strong business market growth, led to a need for updated knowledge in business management techniques and methodologies, to deal with the market changes resulting from economic globalization.

Oliveira (2009) lists seven consulting trends that rep-resent a consolidation of the industry, and its projection, through the demand caused by the search for new knowledge and innovations in light of economic globalization: the search for competitive advantage; consequences of the outsourcing process; the search for continuous improvement; mergers among consulting firms; internationalization of consultancy ser-vices. and finally, the entry of teachers as consultancy providers.

Regarding the services offered by the consultant, we can define the product as the result of a production process aimed at selling in the market, which may be material/tangible or immaterial/intangible. Crocco (2005) defines the consulting product by transforming the provision of services into a material product, by separating the product into three parts called the purchasing set, as follows:

- Core: brings the implicit and apparent quality standard in the offered service identified through the consulting planning time, execution, waiting time to start the work, and perception of the results.

- Facilitators: These are the jobs that are determined to be essential to the success of the consultancy, whether or not they are included in the service. An example would be essential knowledge to perform an administrative routine, or knowledge that should be introduced to the team of employees, through training.

- Support: The works that differentiate the execution of the consulting, for example, the elaboration of a spreadsheet that assists in process controls. 
Oliveira (2009), meanwhile, states that the product offered by a consultant to the market has three components:

The specialty being offered, such as strategic planning, organizational structure, reengineering, management information system, concur-rent engineering, market research, etc.; The consultant's competence and level of knowledge on the subject under consideration; The Consultant's extent and style of action, in view of the best interaction with the reality of the client company (Oliveira, 2009, p. 22).

In general, Block (1991) reiterates that any consultancy procedure is called an intervention, and the consult-ant's goal is to execute successful interventions. Thus, a consultant acts by applying his knowledge, together with the client company, in order to assist in its decision making and indirectly, guide the company in identify and remedying any internal shortfalls, ensuring the efficiency of the consulting in a definitive form.

\section{Profile and type of consultants}

Due to the coverage of the service offered by the consultant, it is important to highlight some important characteristics regarding the qualification, experiences and attitudes of this professional that will differentiate him or her in the market.

For Alves et al. (2015) some actions are essential for a good intervener. Some examples are: the ability to differentiate important scenarios from urgent ones, as depending on the size and time of the project, a poorly established priority can lead to an unsuccessful intervention that could harm rather than benefit the company; be independent of the actions of third parties (managers or employees of the company) and know how to set achievable goals according to the reality of the company; be able to guarantee, to managers and collaborators, the secure implementation of project guidelines; have a clear and objective dialogue, with-out any interference that could harm the consulting process.

In identifying the important characteristics and determinants of the consulting service, several authors have ventured to categorize consultants by type. Oliveira (2009) identifies two types of professional consulting:

- Internal consultant: A member of the company (employee) who has in-depth knowledge of in-ternal procedures, greater engagement with the team of employees, and is present in the company on a daily basis. However, the fact that the consultant is an employee, in direct contact with other employees, reduces his autonomy and power to intervene at all levels of the company's hierarchy, and can make him less impartial.

- $\quad$ External consultant: A professional who performs the role of consultant in full due to his greater acceptance in the superior hierarchical levels of the company, autonomy in the stages of implementation of the consultancy, and ex-tensive experience working in the same function in various situations. However, the external consultant may have a more superficial knowledge of the company's routines, less knowledge of its staff, and less power to act, as he is not a part of the company.

For Orlickas (2001 as cited in Azambuja 2009), consulting can be developed through five types of professionals:

- $\quad$ Freelance Consultant - contracted on a time or project bases, as needed, without any employment relationship, registered as an independent contractor with the municipality of operation;

- $\quad$ Associate Consultant - has no employment relationship with the client company, but is considered its partner;

- $\quad$ Exclusive Consultant - works for a multinational organization, offering personalized service to the company, through a strong relationship of trust; 
- External Consultant - external agent to the client company who, having no link to the organizational hierarchy, has the freedom to issue reliable opinions without restrictions; and

- Internal Consultant - a technician or manager who is an employee of the company, and who therefore has a more in-depth view of the organizational processes.

Block (1991), seeking to identify the consultants' pro-files, describes two types of consultants: a resource consultant, who focuses on knowledge transfer and problem solving, and a procedural consultant, who teaches his approach, methods and values to the company so that the organization itself can diagnose and solve its problems.

Regardless of the consultant's profile or type, Alves et al. $(2015$, p.6) states that: "[...] the consultant must know how to conduct a process within the company. This does not mean executing the process, but having man-agers and executives support his idea and lead according to the procedures the consultant proposes to them."

\section{Structure and stages of consul- ting}

Given that consultancy deals with diverse and complex situations as part of its routines, we can identify some authors who classify the different types of consultancy. According to Oliveira (2009), consulting can be hand-crafted and packaged, whereby:

Package Consulting is performed to client companies through the transfer of strong methodological structures and administrative techniques, without worrying about the optimized adequacy to the current or expected reality for the client company (Oliveira, 2009, p.54).

According to the author, package structure is on the decline, due to the analysis of companies be- ing based on specific analyses. Oliveira goes on to define craft consulting, as:

One that seeks to meet the needs of the client

company through a project based on method-ologies and administrative techniques specifically structured for that client company, but with the support of other approaches and models applied in other companies (Oliveira, 2009, p. 57).

This mode of structuring the provision is more specific and effective, since there is a more indepth work, ac-cording to the needs of the client company and as the author is the most used.

Pereira (1999 as cited in Alves et al., 2015) lists seven types of consulting:

- Prescriptive Consulting: the consultant carries out an analysis of the organization, giving his or her opinion of errors and indicating the correct course of action;

- $\quad$ Risk Consulting: the consultant proposes ways to achieve short-term financial improvement by reducing costs and making changes to the organization chart;

- $\quad$ Resource Allocation Consultancy: The consultant assists in reallocating resources to solve a particular problem;

- Continuing Education Consulting: The consultant gives future projections for the company and develops training;

- Procedural Consulting: the consultant facilitates managers' decision-making, in order to optimize the use of resources;

- Cartase Consulting: The consultant seeks to create a favorable climate in which employees can express their feelings, optimizing the organizational culture;

- Action Research Consulting: The consultant documents the changes in the organization and comes back to the management to decide on the direction of the organization. For 
success in this model, both the client and the consultant are involved.

Shein (1972) mentions the nature of consulting as:

1) Specialized Purchase Model: The consultant is an expert and sells his specialized product; 2) Patient medical model: [...] The consultant makes his diagnosis and proposes solutions; 3 ) The focus is on the client's own perception to understand and act on the interrelated factors that occur in the environment. (While Shein, 1972 as cited in Alves et al., 2015, p.5)

Block (1991) lists five phases of consulting that enable us to understand the consulting processes in a simplified way:

- Entry and contract: Consists of the initial meeting with the client company, defining the problem to be resolved, verifying whether the consultant has the right skills to deal with the problem, identifying the client's expectations, and starting the project.

- Data collection and diagnosis: This phase will define which of the company's employees will be involved in the problem definition process, the methods to be used, the choice of types of data to be collected for analysis, and diagnosis and length of the consulting.

- $\quad$ Feedback and decision to act: This phase sets the ultimate gals of the project and enables greater success in indicating the path of action or intervention.

- Implementation: The consultant may or may not be invited to hold meetings to introduce changes to company processes, training sessions for employees, or a general meeting that will bring employees together to solve the company's problem.

- $\quad$ Extension, retraining or termination: In the final phase of the process, identifying the success or failure of the consultant's work is crucial, to determine whether the relationship between the consultant and the client company should end, or be extended to other projects.

Oliveira (2009) points out seven steps for planning business consulting:

- Identification: Recognizing the reality of the client company;

- $\quad$ Entry: Drawing up the contract, signing a document of expectations and mutual commitments, establishing the consultant's work targets, identifying the environment, culture and receptivity of the clientcompany's employees, and conducting a survey of dissatisfaction and problems in the company.

- Position audit: conducting interviews and surveys to gather data, analyzing, defining the reality and changes in the environment, identifying and driving the solution, analyzing alternatives, effects, risks, costs, resistances, accommodation and other factors, assessing potential for change, and defining system weaknesses and strengths at work.

- $\quad$ Planning: determining strategies and alternatives for developing the consulting, defining strategy policies, defining which employees will be in-volved in the project, and their roles, and establishing the details of the project (time, resources, sequence of actions, and others)

- Action: operationalizing the work plan, acting on the system under consideration, training staff, establishing the structures of changes through resolution methods and attitudes.

- Monitoring and evaluation: controlling the results, self-evaluation of users, evaluating the process and studying the needs in accordance with the new reality of the company.

- Conclusion: Terminating the process, whether definitively or temporary.

\section{SEBRAE-AM Consulting}

The Micro and Small Business Support Service SEBRAE - was started in 1990 based on Laws 8,029 and 8,154 at the initiative of the executive branch and regulated by Decree 99,570 in the same year, to meet the demand from entrepreneurs. However, although the institution arose out of a political decision, it is run by the private sector. 
SEBRAE's mission is to "promote the competitiveness and sustainable development of micro and small enterprises and foster entrepreneurship". In terms of Vision, SEBRAE seeks "excellence in the development of micro and small companies, contributing to the construction of a fairer, more competitive and sustainable Brazil". As for the quality policy of the institution, it aims to "stimulate the appearance and promote the development of entrepreneurs, micro and small companies and organized groups, enabling them to remain in the mar-ket and [to promote] selfeconomic and environmental sustainability, seeking continuous improvement of the processes and services offered".

SEBRAE operates throughout the country, providing various activities, such as trade fairs, exhibitions, courses and programs, for entrepreneurs seeking to improve their businesses.

Dornelas (2005) adds that the institution organizes delegations to visit trade fairs and exhibitions, supports business incubators, provides assistance to companies in matters related to foreign trade, and other activities that promote knowledge for the development of successful enterprises.

In the area of consultancy, SEBRAE adopts the concept of interactive process, developed based on the client's demand for change, the diagnosis carried out, the expected results, and a relationship of co-responsibility between all those involved, working in collaboration. The concept of consulting adopted by the institution involves this process of interaction, which is a logical and evolutionary structure that seeks to meet the client's expectations and promote changes in the company, the life cycle of which reflects the reactions of means in which they are inserted (SEBRAE, 2012).

In the integrated view of SEBRAE, consulting should always start with a diagnosis of the company's reality, and should end with the assimilation of new methods, knowledge, tools and techniques, by the company, that will bring better results. The consulting service should be hired based on this diagnosis, as this process will enable the consultant to prepare the proposal and/or plan of action, based on which a contract is then signed between the parts.
SEBRAE provides face-to-face consultancy services, at its own facilities, and also remotely by telephone or the internet. It may work with individuals, focusing on a single client, or with groups of clients.

The types of consultancy provided by the institution may include the following subjects:

Management Consulting: Its execution is focused on solving the difficulties that the company has regarding its management, covering planning, strategy, marketing, finance and people management. It can be used to better understand the current and future scenarios and trends in which the company operates; Techno-logical Consulting: Focused on improvements to the company's technological aspects, such as product and productive process improvement, product development, and the identification of new technologies available in the market that can improve the company's productive results (SEBRAE, 2012, p.73).

It was noted, in the previous chapter, that there are various methods and perspectives for using and analyzing consulting. Understanding the dimensions of the process, SEBRAE has chosen a model for conducting its consultancy process, which establishes a standard of care for the different services provided by the institution, except in cases where another, specific model is needed for a particular type of intervention.

Finally, it is understood that although SEBRAE acts as an intermediary between the consultant and the client-company, the consultancy process itself, according to the "SEBRAE Consulting References", remains the same in particular form. But coresponsibility and the standard of care are characteristics that SEBRAE offers. In view of the importance of the SEBRAE consulting ser-vices, it is necessary to understand in more depth how the consulting services offered by SEBRAE-AM are per -formed, for companies in the tourism sector of the city of Manaus. 


\section{Metodology}

Seeking to contribute to the generation of consulting knowledge in tourism companies, both for academics and for the market, this research analyzes the provision of services offered by SEBRAEAM. This case study therefore sought to investigate the process of tourism consultancy in the State of Amazonas in a broad and in-depth way. According to Gil (2008, p. 57) "The case study is characterized by the deep and exhaustive study of one or a few objects, in order to allow their broad and detailed knowledge, a task practically impossible through the other types of designs considered".

Regarding the methodological aspects of the research, we sought to gain greater familiarity with the theme of consulting, as this is little discussed in the academic and scientific scope, and the few studies that have been conducted require further investigations. There-fore, for this research, an exploratory method was used, which deals with "empirical research investigations where the objective is to formulate an issue or problem" aimed at [...], "increasing the researcher's familiarity with an environment, fact or phenomenon, for the performance of a more precise future research or to modify and clarify concepts "(Marconi \& Lakatos, 2003, p. 188).

In terms of approach, a qualitative methodology was chosen, enabling the study of the particularities of each individual in the research universe the team of about seven consulting professionals of SEBRAE-AM who work directly with tourism - in order to obtain their points of view on the reality of the consulting process.

The instruments used were semi-structured interviews and bibliographic research, in an attempt to present a theoretical discussion that was appropriate to the understanding of the research object.

Intentional non-probabilistic sampling was used to select respondents for participation in the study. No statistical resources were used in this choice, only a brief analysis of the experience of each consultant. Preference was given to those who had been at the institution for longer, resulting in the selection of three professionals: a manager responsible for the tourist consultancy sector, in which he represents the institution, and two outsourced consultants whose services are brokered by SEBRAE-AM. The three participants are randomly referred to as $\mathrm{C} 1, \mathrm{C} 2$ and $\mathrm{C} 3$ in the analysis of the results.

For Marconi and Lakatos (2003, p. 163), "The sample is a conveniently selected portion of the universe (population); it is a subset of the universe".

The treatment and analysis of the data were initially performed by applying semi-structured interviews using a recorder, and later, full transcription of the texts. However, to save time on the exhaustive transcriptions, only the information that is relevant to the concerns of the research was extracted and analyzed, in order to present results about the reality found.

\section{Results and discussions}

As presented in the methodology, the results were obtained through interviews, applied during 2018 accord-ing to the respondent's availability, recorded with the consent of each individual, and transcribed, to provide results on following topics:

- Forms of consultant's admission to the SEBRAE-AM system;

- $\quad$ Structure of consulting services provided through SEBRAE-AM;

- Evaluation of the consulting services and the consultants;

- Use of consulting in processes relevant to tourism in Amazonas;

- Benefits, limitations and demands of the consulting process in tourist companies brokered by SEBRAE;

- The tourism market in Amazonas, from the perspective of the consultancy professionals.

To obtain search results based on the method de- 
veloped by Pereira et al. (2011). Frameworks for analysis were prepared that would allow a stratified view of the required approach, i.e., within the framework, the main issue developed on the topic is selected; this is later divided into sub issues that allow a more in-depth analysis of the subject, then after analyzing the transcripts of the interviews, the characteristics that best answer the questions, in the author's opinion, are recorded in the "results" column. Finally, these are highlighted in the "Analyzed Records" comprising excerpts from the interview claiming the result deduced by the researcher.

\section{Forms of entry of consultants to SEBRAE}

In order to analyze the data from the survey, tables were drawn up according to the topic discussed in the results. The table below shows the forms of entry of consultants to SEBRAE-AM, since this information could not be obtained through a literature search. The consultants were asked about their forms of accreditation, the phases of the selection process, and their training to act as consultants with SEBRAE-AM. The results are shown in Table 01:

Table 01 - Data analysis about forms of accreditation at SEBRAE.

\begin{tabular}{|c|c|c|c|}
\hline ISSUES & SUB ISSUES & RESULT & CONSIDERED REGISTRATION \\
\hline \multirow{9}{*}{$\begin{array}{l}\text { Forms of consultant's } \\
\text { entry to SEBRAE-AM }\end{array}$} & \multirow{3}{*}{$\begin{array}{l}\text { Means of accredi- } \\
\text { tation by SEBRAE }\end{array}$} & \multirow{3}{*}{$\begin{array}{l}\text { Open public } \\
\text { tender sent } \\
\text { to consulting } \\
\quad \text { firms }\end{array}$} & $\begin{array}{l}\text { C1: a system that we call is SGC that is consultants' genera- } \\
\text { tional system, consultant management where the tender is } \\
\text { open to the public and then the consultant applies for ac- }\end{array}$ \\
\hline & & & $\begin{array}{l}\mathrm{C} 2:[\ldots] \text { it was through a process of public tender in which I } \\
\text { wrote my existing business. }\end{array}$ \\
\hline & & & $\begin{array}{l}\text {.C3: they opened a new tender for accreditation, and this is } \\
\text { the methodology that is used up to today, then they re- } \\
\text { lease tenders every year for consultant's accreditation, you } \\
\text { have to meet the requirements of the tender. }\end{array}$ \\
\hline & \multirow{6}{*}{$\begin{array}{l}\text { Phases in the selec- } \\
\text { tion process and } \\
\text { initial } \\
\text { training }\end{array}$} & \multirow{3}{*}{$\begin{array}{l}\text { Written eval- } \\
\text { uation and } \\
\text { interview by } \\
\text { an examin- } \\
\text { ing board. }\end{array}$} & $\begin{array}{l}\text { C1: If he is qualified, he is asked to an interview and do an } \\
\text { exam. }\end{array}$ \\
\hline & & & C2: did not mention the subject \\
\hline & & & $\begin{array}{l}\text { C3: then you go through an assessment of both written and } \\
\text { oral banking evaluation. }\end{array}$ \\
\hline & & \multirow{3}{*}{$\begin{array}{l}\text { Training for } \\
\text { internal pro- } \\
\text { vision of } \\
\text { consulting } \\
\text { processes }\end{array}$} & $\begin{array}{l}\text { C1: the training is how the system will work, as it is the } \\
\text { "form" that it will have to enter the system to do reports, } \\
\text { forms of delivering reports, for this there will be this train- } \\
\text { ing, it will not be specific to the area. }\end{array}$ \\
\hline & & & C2: did not mention the subject \\
\hline & & & $\begin{array}{l}\text { C3: They (SEBRAE) already have a methodology defined, so } \\
\text { they have some programs that are already installed, you } \\
\text { are trained by them to do this kind of service to companies, } \\
\text { so you have to work on that line you received training. }\end{array}$ \\
\hline
\end{tabular}

The selection is processed through the following steps, as shown in Figure 01:

Figure 01 - Steps the SEBRAE selection process of 2018.

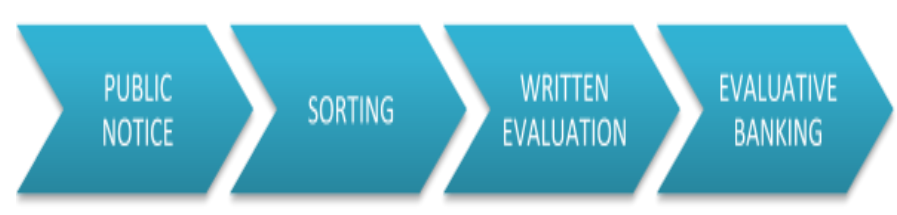


According to respondents, the accreditation for SEBRAE-AM, as at the time of this study, is by open public tender to companies operating in the field, i.e. applicants must have proven experience in providing consulting services.

Concerning the training, it was observed that the consultants go through a proper training process offered by SEBRAE, aimed at standardizing the services provided by its employees. They receive instructions on how to provide the services in standardized ways, as re-quired by the institution.

\section{Structure of consultations}

\section{provided through SEBRAE-AM}

This topic focuses on the consulting structures provided through SEBRAE-AM, and is divided by the types of consulting provided by the institution and the work chronology proposed for accredited consultants.

The interviews showed similar processes to the phase structure presented by Block (1991), who presents five steps that make up the consultancy cycle: entry and initial contract, data collection and diagnosis, feedback and decision to act, im- plementation, and finally, re-training or termination. However, in the case of SEBRAE, the phases of entry and initial contract, data collection and diagnosis are performed by the institution's manager. The consultant performs the steps of feedback and decision to act, implementation or extension, and retraining or termination.

In more detail, from the moment the tourist company makes a request for the consultancy service, this is for-warded to the manager, who will analyze the business needs of the client. The case is then passed on to a specialized professional in the field. Cases are allocated to consultants by rotation, and it is the manager who decides on the time needed to for the consultant to provide the advice.

When designing the structure for a collective service involving a group of companies, a market analysis is carried out, to identify the needs and vulnerabilities of a particular segment. Based on this diagnosis, projects are developed to resolve the weaknesses identified points. Once the project is formatted, the consultants are trained to bring the necessary knowledge to the client companies and later the audience is invited to participate, as shown in the reports listed in Table 02 below:

Table 02 - SEBRAE consultants structure Analysis.

\begin{tabular}{|c|c|c|c|}
\hline ISSUES & SUB ISSUES & RESULT & CONSIDERED RECISTRATION \\
\hline \multirow{3}{*}{$\begin{array}{l}\text { Structure of } \\
\text { consultants } \\
\text { provided } \\
\text { through } \\
\text { SEBRAE-AM }\end{array}$} & \multirow{3}{*}{$\begin{array}{l}\text { Kind of Consul- } \\
\text { ting }\end{array}$} & \multirow{3}{*}{$\begin{array}{l}\text { Specific diag- } \\
\text { nosis and } \\
\text { Structural Pro- } \\
\text { jects for } \\
\text { attendance to } \\
\text { business group }\end{array}$} & $\begin{array}{l}\text { Diagnosis. [...] a standard procedure that all consultants must follow. } \\
\text { In some situations, this diagnosis is not necessary because it is visi- } \\
\text { ble; depending on the area [...] a project is carried out with that } \\
\text { group in the labor market, only entrepreneurs are engaged [...] they } \\
\text { draw up a plan; [...] the individual projects, for example it just neces- } \\
\text { sary to go to the service and say, I want to do a consultancy, it is indi- } \\
\text { vidual. }\end{array}$ \\
\hline & & & $\begin{array}{l}\text { C2: SEBRAE works many closed programs at National level; we do a } \\
\text { kind of survey we call a diagnosis. }\end{array}$ \\
\hline & & & $\begin{array}{l}\text { C3: SEBRAE's specifically attendings are structural, what it is, they } \\
\text { already have a proper defined methodology [...]; SEBRAE, actually, } \\
\text { works from projects, but it thinks the project for a specific audience } \\
\text { and invites this audience to participate; they will just send you de- } \\
\text { mands of what you have been trained by them. }\end{array}$ \\
\hline
\end{tabular}




\begin{tabular}{|c|c|c|c|}
\hline ISSUES & SUB ISSUES & RESULT & CONSIDERED REGISTRATION \\
\hline \multirow{3}{*}{$\begin{array}{l}\text { Structure of } \\
\text { consultants } \\
\text { provided } \\
\text { through } \\
\text { SEBRAE-AM }\end{array}$} & \multirow{3}{*}{ Work Timeline } & \multirow{3}{*}{$\begin{array}{l}\text { Diagnosis } \\
\text { made by } \\
\text { SEBRAE's man- } \\
\text { ager, about the } \\
\text { actual needs of } \\
\text { the company, } \\
\text { assigning the } \\
\text { most special- } \\
\text { ized profes- } \\
\text { sional in the } \\
\text { field and defin- } \\
\text { ing a timeline } \\
\text { for the consul- } \\
\text { tancy service. }\end{array}$} & $\begin{array}{l}\text { C1: A consultant will do an activity in the company "A". I go there in } \\
\text { the company, talk to the manager, I see the actual need and then I } \\
\text { see which consultant fits there. }\end{array}$ \\
\hline & & & $\begin{array}{l}\text { C2: The area manager, manager, requests the service of a licensed } \\
\text { counselor, from an accredited company, and then he says what he } \\
\text { needs concerned the consulting. }\end{array}$ \\
\hline & & & $\begin{array}{l}\text { C3: SEBRAE also has defined programs, they themselves already stip- } \\
\text { ulate that by workload. }\end{array}$ \\
\hline
\end{tabular}

\section{Evaluation of the consulting pro-cess and the consultants}

Given that inefficiency in the consulting process can be detrimental to the client company, it is necessary to check how the institution evaluates its internal processes and its consultants. For this, it was set as a matter the evaluation of the consulting process and consultant in SEBRAE-AM, and for a greater use of analysis sub-issues were determined: evaluation of the effectiveness of the consulting, assessment of the consultant, and measures taken in the case of inefficiency of the service.

Regarding the evaluation of the effectiveness of the consultancy provided through SEBRAE, the form of evaluation of specific consultancies provided by the institution is done from the trimmings of the consultation process, through all its steps up to the delivery of the Strategic Management Report Oriented (GEO) of the results, signed by the client company at the end of each consultancy, end of each consultancy, which, according to what was reported in the research, the customer's signature on the document certifies the effec- tiveness of the service provided by the consultant. There is also a system called SGC in which the manager himself evaluates the service provided by the consultant, to verify that it has met the requirements of the contract.

The evaluation of the planned consultancy services is done twice a year, when the client companies served by the programs are invited to fill out a satisfaction survey that assesses both the consultants and the results achieved through the project. Also, to assess consultants accredited by SEBRAE-AM, the institution con-ducts an annual service and periodic reviews, and seeks to continually retrain its consultants and stimulate improvements in the system overall. These actions are shown in Table 03: 
Table 03 - Analysis of evaluations forms to consultant and SEBRAE consulting.

\begin{tabular}{|c|c|c|c|}
\hline ISSUES & SUB ISSUES & RESULT & CONSIDERED REGISTRATION \\
\hline \multirow{9}{*}{$\begin{array}{l}\text { Evaluation of the } \\
\text { consulting services } \\
\text { and the consultants } \\
\text { of SEBRAE-AM }\end{array}$} & \multirow{3}{*}{$\begin{array}{l}\text { Evaluation of } \\
\text { the effective- } \\
\text { ness of the } \\
\text { consulting } \\
\text { service }\end{array}$} & \multirow{3}{*}{$\begin{array}{l}\text { Strategic Manage- } \\
\text { ment Report Ori- } \\
\text { ented for Results } \\
\text { signed by the cli- } \\
\text { ent company; Bi- } \\
\text { annual satisfaction } \\
\text { survey as a result } \\
\text { of the projects; } \\
\text { Monitoring the } \\
\text { beginning, middle } \\
\text { and end of the } \\
\text { consultations. }\end{array}$} & $\begin{array}{l}\text { C1: [...] it will give me a report with the criteria [...] GEO re- } \\
\text { port, which is the strategic oriented management for results. } \\
\text { I will only receive this report when he (the client) signs, be- } \\
\text { cause it will attest your activity, [...] report that is mandatory; } \\
\text { (For projects) there are two surveys, a year satisfaction, but } \\
\text { it's with that group of entrepreneurs. It is not individual. We } \\
\text { call these } t 1, t 2, t 3 \text {. These searches are the result of each } \\
\text { project. }\end{array}$ \\
\hline & & & $\begin{array}{l}\mathrm{C} 2:[\ldots] \text { there is the GEOs [...], so we have to have the signa- } \\
\text { ture of the people we work for, their CPF, we must have } \\
\text { many times photography. }\end{array}$ \\
\hline & & & $\begin{array}{l}\text { C3 There is a report that will be delivered in service and } \\
\text { SEBRAE follows up with the owners to find out whether the } \\
\text { service was affective, and it is this form that they must evalu- } \\
\text { ate. So, it has a range goals scheduled for the beginning, mid- } \\
\text { dle and end. }\end{array}$ \\
\hline & \multirow{3}{*}{$\begin{array}{l}\text { Evaluation of } \\
\text { the consultant }\end{array}$} & \multirow{3}{*}{$\begin{array}{l}\text { Annual evaluative } \\
\text { survey; periodic } \\
\text { reassessment of } \\
\text { accredited consult- } \\
\quad \text { ants. }\end{array}$} & $\begin{array}{l}\text { C1: An evaluation survey is conducted annually, with the en- } \\
\text { trepreneur and the consultant himself. We [...] do constant } \\
\text { monitoring; the manager is obliged to follow all the activities } \\
\text { that the consultant is carrying out, and discuss them with } \\
\text { him. }\end{array}$ \\
\hline & & & $\begin{array}{l}\text { C2: I have participated in other programs where I was asked } \\
\text { to find out whether, in fact, the agents had really made the } \\
\text { visits they claimed. }\end{array}$ \\
\hline & & & $\begin{array}{l}\text { C3: SEBRAE also periodically calls the consultants in its data- } \\
\text { base, for a reevaluation; }\end{array}$ \\
\hline & \multirow{3}{*}{$\begin{array}{l}\text { Measures tak- } \\
\text { en in case of } \\
\text { inefficiency of } \\
\text { the service } \\
\text { provided }\end{array}$} & \multirow{3}{*}{$\begin{array}{l}\text { Preventive meas- } \\
\text { ure: Repeat the } \\
\text { consulting service } \\
\text { without fees to the } \\
\text { client company; } \\
\text { Transfer the client } \\
\text { to another accred- } \\
\text { ited consultant; } \\
\text { Punishment: re- } \\
\text { moval from } \\
\text { SEBRAE's database } \\
\text { of consultants for } \\
\text { up two years (if } \\
\text { already settled } \\
\text { income related to } \\
\text { the service) or } \\
\text { disqualification. }\end{array}$} & $\begin{array}{l}\text { C1: Well, first we do a preventive measure and call the con- } \\
\text { sultant: look, the entrepreneur did not like this activity and } \\
\text { we'll talk to the manager if he is interested and we can redo } \\
\text { the work, he has the chance to redo the job or if he cannot } \\
\text { take it, I will have to pass it to another consultant, whom the } \\
\text { entrepreneur will not pay anymore, and this consultant is } \\
\text { punished. [...] for up two years if it is paid, [...] or even dis- } \\
\text { qualified. }\end{array}$ \\
\hline & & & C2: did not mention the subject \\
\hline & & & C3: did not mention the subject \\
\hline
\end{tabular}

In cases where the consultancy provided is ineffective, the institution adopts a preventive measure in which the client is initially offered a repeat consultancy with the same consultant, with no fees charged. If the client does not want that, then they are offered another consultant. If the service is still unsuccessful, payment is refunded to the client and the original consultant is not paid for the service. In some cases, the consultant may be removed from SEBRAE's database for up to two years, or disqualified. 


\section{Use OF CONSULTING IN TOURISM in Amazonas}

Seeking to demonstrate the use of consulting process for tourism in Amazonas, the consultants were asked which were the most significant experiences in providing tourism consulting. In response, we received re ports of participation in significant projects in Amazonas: The Riverside Entrepreneurship Project and Routing Plan of Route 174. It can therefore be seen that the consulting process can and has helped improve the tourism market in the region.

The Riverside Entrepreneurship Project was applied in twenty municipalities in nine protected areas (PAs). It aims to identify the main difficulties in the production chains of communities and provide training for community entrepreneurs. About five thousand people were assisted, with suggestions for 45 training courses in 15 productive chains including flour, açaí, vegetable oil, and tourism. In general, SEBRAE-AM was responsible for organizing and implementing the diagnosis, and conducting specific studies, courses and training for community entrepreneurs.
The Routing plan of Route 174: The Regionalization Tourism Program - Routes of Brazil (2010) nationwide proposed structuring intercity tourist routes, instituting tourist routing as one of the main tactics to achieve diversification of supply, through the introduction of differentiated products in the domestic and international markets. For the northern region, route 174 (Amazonas Roraima) was used, aiming to give an overview of the Amazonas region and its characteristics. The destinations selected were: Manaus, Presidente Figueiredo, Balbina Vila Boa Vista, Caracaraí Pacaraima, Amajari, and Rorainópolis.

\section{BeNefITS, LIMITATIONS AND DE- MAND FOR CONSULTING SERVICES AMONG TOURISM BUSINESSES}

In view of the long history of SEBRAE in Amazonas, we sought to understand the motives that lead tourism companies to seek out its consulting services, and to demonstrate the benefits and limitations that micro and small entrepreneurs can obtain when hiring consulting services through SEBRAE-AM. The results are shown in Table 04:

Table 04 - Analysis of the benefits, limitations and demand for SEBRAE consulting services.

\begin{tabular}{|c|c|c|c|}
\hline ISSUE & SUB ISSUE & RESULT & CONSIDERED REGISTRATIION \\
\hline \multirow{5}{*}{$\begin{array}{l}\text { Benefits and limi- } \\
\text { tations, and de- } \\
\text { mand for } \\
\text { SEBRAE's con- } \\
\text { sulting service by } \\
\text { tourism compa- } \\
\text { nies brokered by } \\
\text { SEBRAE }\end{array}$} & \multirow{5}{*}{$\begin{array}{l}\text { Demand for } \\
\text { SEBRAE Con- } \\
\text { sulting services }\end{array}$} & \multirow{5}{*}{$\begin{array}{l}\text { The demand is } \\
\text { due to a need to } \\
\text { keep up-to-date } \\
\text { with the new } \\
\text { realities of the } \\
\text { market and gen- } \\
\text { eral guidelines; }\end{array}$} & $\begin{array}{l}\text { C1: it always happens [...]. In the market, after a year or two, progress oc- } \\
\text { curs, and it has to be done again, the entrepreneur himself, who at the time } \\
\text { said he was ok, that he was getting it, then got lost and then you will have to } \\
\text { have a kind of continuous monitoring. We provide on average three ser- } \\
\text { vices, activities, per company per year, in more complex consulting, mar- } \\
\text { keting, finance, management. }\end{array}$ \\
\hline & & & $\begin{array}{l}\text { C2: We try to inject innovation so that they seek SEBRAE again is explained } \\
\text { that despite being a specific work segmentation, they need to have other } \\
\text { survival resources, but there is a return failure; [...] then it's just that time } \\
\text { because there is a SEBRAE program that will act within the municipality and } \\
\text { within the tourism ventures and out of it they do not seek for SEBRAE and } \\
\text { again for working. }\end{array}$ \\
\hline & & & $\begin{array}{l}\text { C3: SEBRAE has this image to help micro and small entrepreneurs, so they } \\
\text { come to seek for SEBRAE to have some kind of guidance; they always come } \\
\text { back, but in the rotation system [..] }\end{array}$ \\
\hline & & & $\begin{array}{l}{[. . .] \text { in some cases, more time is needed, this could be more flexible because }} \\
\text { our contract ended there. }\end{array}$ \\
\hline & & & $\begin{array}{l}\text { C3: SEBRAE has a limitation in its services that it will provide you with a con- } \\
\text { sultant for certain hours, providing the service within its methodology, but } \\
\text { for anything outside of that, it can no longer serve you; in the rotation sys- } \\
\text { tem you may or may not get the same consultant. }\end{array}$ \\
\hline
\end{tabular}




\begin{tabular}{|c|c|c|c|}
\hline ISSUE & SUB ISSUE & RESULT & CONSIDERED REGISTRATION \\
\hline \multirow{4}{*}{$\begin{array}{l}\text { Benefits and } \\
\text { limitations, } \\
\text { and demand } \\
\text { for SEBRAE's } \\
\text { consulting } \\
\text { service by } \\
\text { tourism com- } \\
\text { panies bro- } \\
\text { kered by } \\
\text { SEBRAE }\end{array}$} & $\begin{array}{l}\text { Limitations } \\
\text { of the Con- } \\
\text { sultant in } \\
\text { providing } \\
\text { the service }\end{array}$ & $\begin{array}{l}\text { Average number } \\
\text { of services per } \\
\text { year; time taken } \\
\text { to providing stip- } \\
\text { ulated services; } \\
\text { Limitations in } \\
\text { continuing the } \\
\text { service due to } \\
\text { time constraints } \\
\text { and to the rota- } \\
\text { tion system } \\
\text { among consult- } \\
\text { ants. } \\
\end{array}$ & $\begin{array}{l}\text { C1: We provide, on average, } 3 \text { service activities per company per year. } \\
\text { C3: SEBRAE has a limitation in its service; it gives you a consultant for certain length } \\
\text { of time, providing you with the consulting within its own methodology. Anything } \\
\text { outside of that and it can no longer attend you; in the rotation system, you may or } \\
\text { may not get the same consultant. }\end{array}$ \\
\hline & \multirow{3}{*}{$\begin{array}{l}\text { Benefits of } \\
\text { joining the } \\
\text { SEBRAE } \\
\text { consulting } \\
\text { service }\end{array}$} & \multirow{3}{*}{$\begin{array}{l}\text { Free activities and } \\
\text { guidelines; } 50 \% \\
\text { to } 70 \% \text { discount } \\
\text { for the acquisition } \\
\text { of more complex } \\
\text { services; Possibil- } \\
\text { ity of payment by } \\
\text { instalments. }\end{array}$} & $\begin{array}{l}\text { C1: There are some activities that are for free, but there are other, more complex } \\
\text { ones for which the business has to pay. On average, the business pays } 30 \% \text { and } \\
\text { SEBRAE pays } 70 \% \text {. Some activities are split } 50-50 \% \text {, and so on, it depends on the } \\
\text { complexity. For example, the benchmarking activity, will choose a destination for } \\
\text { visiting that particular place with success story, SEBRAE pays 50\% of the package } \\
\text { the entrepreneur pays the other 50\%, and further installments. }\end{array}$ \\
\hline & & & $\mathrm{C} 2$ : did not mention the subject \\
\hline & & & $\begin{array}{l}\text { C3: SEBRAE has many services that are free of charge, so you do not have any kind } \\
\text { of investment [...]; many of SEBRAE's products are paid, [...] SEBRAE hires the con- } \\
\text { sultant to provide the service to that or those companies, but this service is subsi- }\end{array}$ \\
\hline
\end{tabular}

Concerning the demand for SEBRAE's services, it is noted that tourism companies in Amazonas are motivated to seek out the consulting services because of the continuing restructuring in the tourism market. Hence, there is a perceived need to update their knowledge, training and guidance, to stimulate the quality of these micro and small businesses, as an essential factor for improving their competitiveness in the tourism market in the state.

Regarding to the benefits of acquiring the consulting service through SEBRAE, the institution provides quality services that are competitive in the market, without needing high investments. For example, there are guidelines and free services, and more complex ser-vices are heavily subsidized, with the institution bearing $50 \%$ to $70 \%$ of the real value of the, reducing the investment required by the client company. It also offers the possibility of payment by instalments for the services purchased. This benefits are shown in Figure 02:

Figure 02. Consulting Benefits brokered by SEBRAE.

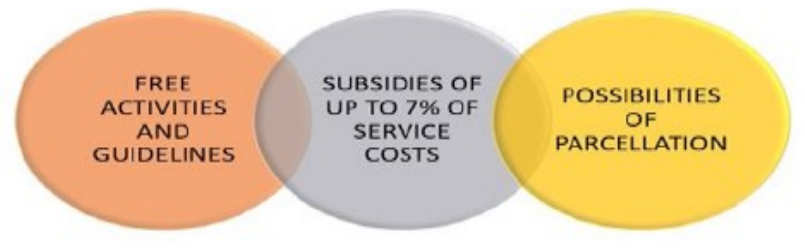

Concerned the limitations of SEBRAE'S consultancy service, the one most mentioned by the respondents was the time allocated to the service by the institution, which in some cases was insufficient, thus leaving some gaps. Another situation mentioned as a concern was the consultants rotation system, which did not provide continuity between one service and the next.

\section{THE TOURIST MARKET IN AMAZO- NAS FROM THE CONSULTANT'S PER- SPECTIVE}

After analyzing the consulting offered by SEBRAE, and the experience of its team of professionals in projects in Amazonas, we focused on the perspective of the consultants and the institution's manager for tourist market in the State. Some sub -issues were established, such as weaknesses of the tourist market in Amazonas, the obstacles found that hinder the expansion of the consulting services of SEBRAE-AM, and the steps the institution is taking to improve the process. These are shown in Table 05: 
Table 05 - Analysis of the Amazonia tourism market from the consultants' perspective.

\begin{tabular}{|c|c|c|c|}
\hline ISSUES & SUB ISSUES & RESULT & CONSIDERED REGISTRATION \\
\hline \multirow{10}{*}{ Market in Amazonas } & \multirow{4}{*}{$\begin{array}{l}\text { Weaknesses of the } \\
\text { tourist market in } \\
\text { Amazonas in the } \\
\text { respondent's view. }\end{array}$} & \multirow{4}{*}{$\begin{array}{l}\text { Knowledge of } \\
\text { limitations on the } \\
\text { tourist market by } \\
\text { the consultants: } \\
\text { Fragility in the } \\
\text { consolidation of } \\
\text { the tourism mar- } \\
\text { ket; Lack of de- } \\
\text { mand for training } \\
\text { and consulting by } \\
\text { entrepreneurs. }\end{array}$} & $\begin{array}{l}\text { C1: Tourism businesses are usually very small, sometimes it's one or two employees } \\
\text { at most, so how can we remove the entrepreneur to put them in the classroom? } \\
\text { Sometimes it is very difficult. }\end{array}$ \\
\hline & & & $\begin{array}{l}\text { C2: There is no }[\ldots] \text { appreciation or recognition of the professional trained here, the } \\
\text { market is too closed and I see it by looking many behaviors. }\end{array}$ \\
\hline & & & $\begin{array}{l}\text { C3: [...] it is a market that still depends on an organization, right? so to work with it, } \\
\text { specifically for tourism businesses, for us who do not have the culture of an orga- } \\
\text { nized tourist market, it is a big challenge. }\end{array}$ \\
\hline & & & $\begin{array}{l}\text { C3: I've seen a lot out there, a lot of people working in tourism are not from the } \\
\text { area, a lot of people working with tourism as a second activity, and a lot of people } \\
\text { working in tourism in the informal sector, but that is a macro issue, also involving } \\
\text { the control units, so I'm talking about both fiscal control bodies and tourism control. } \\
\text { So you see, downtown, many hotels that are not hotels, many agencies that work } \\
\text { without even having registered companies, you see "many guides" that are not } \\
\text { accredited by the Ministry [of Tourism], then it is a market that still depends on an } \\
\text { organization right then so, work with it, specifically for tourism agencies, for us who } \\
\text { do not have the culture of organized tourist market, it is a big challenge. }\end{array}$ \\
\hline & \multirow[b]{3}{*}{$\begin{array}{l}\text { Hindrances to the } \\
\text { expansion of tour- } \\
\text { ism consulting ser- } \\
\text { vices of SEBRAE -AM }\end{array}$} & \multirow{3}{*}{$\begin{array}{l}\text { Lack of skilled } \\
\text { professionals with } \\
\text { experience in } \\
\text { tourism; Depend- } \\
\text { ence on the adhe- } \\
\text { sion of client com- } \\
\text { panies in Amazo- } \\
\text { nas; Immateriality } \\
\text { of consulting ser- } \\
\text { vices; lack of speci- } \\
\text { fication of the } \\
\text { offer by the com- } \\
\text { panies; Stigma of } \\
\text { the term } \\
\text { "consultant". }\end{array}$} & $\begin{array}{l}\text { C1: The biggest difficulty is finding a qualified consultant, with experience, because } \\
\text { there are specific areas that do not have enough tourism consultants with qualifica- } \\
\text { tion for tourism, who have specialized himself, sought to consulting it is very diffi- } \\
\text { cult, and then there are other consultants from other areas that end up going into } \\
\text { tourism. }\end{array}$ \\
\hline & & & $\begin{array}{l}\text { C2: The cultural issue at all that we have, so most companies are family businesses. } \\
\text { It worked that way, then keep doing it the same way. }\end{array}$ \\
\hline & & & $\begin{array}{l}\text { C3: It depends a lot on the interest and the adhesion of these companies and their } \\
\text { wish to participate; SEBRAE works only with micro and small businesses, so except } \\
\text { for companies that are not SEBRAE's public, companies must want to be served by } \\
\text { SEBRAE too, and that comes through projects that are already structured for them; } \\
\text { It is a cultural issue, to reconcile a consultant as an acquisition of knowledge you are } \\
\text { not buying one, you are buying what he's looking for helping you; you make the } \\
\text { entrepreneurs to look to where they want to go, it is very challenging; the term } \\
\text { consultant is already a business kind of "undeserving", because the "guy" sells you, } \\
\text { then he is a seller, [...] then there is that issue of stigma. }\end{array}$ \\
\hline & \multirow{3}{*}{$\begin{array}{l}\text { Corrective measures } \\
\text { to improve SEBRAE- } \\
\text { AM consultancy } \\
\text { system. }\end{array}$} & \multirow{3}{*}{$\begin{array}{l}\text { Restructuring of } \\
\text { tourist advice } \\
\text { offered by SEBRAE- } \\
\text { AM; Reduction and } \\
\text { screening of ac- } \\
\text { credited consult- } \\
\text { ants; Search for } \\
\text { more qualified } \\
\text { professionals in } \\
\text { tourism; Constant } \\
\text { qualification and } \\
\text { systematic evalua- } \\
\text { tion with the cli- } \\
\text { ent; Implementa- } \\
\text { tion of Normative } \\
\text { Instructions; Iden- } \\
\text { tify the best way to } \\
\text { contribute to the } \\
\text { tourist companies. }\end{array}$} & $\begin{array}{l}\text { C1 Tourism SEBRAE is undergoing a restructuring, in fact we had a very large number } \\
\text { of consultants, then it has been dried [...] so it is happening this screening for us to } \\
\text { be always able to qualify these consultants, making a more systematic assessment of } \\
\text { this consultant, with the company, more detailed, so now if I told you how it will be } \\
\text { done, we have created here, what we call normative instruction (iN's), which will } \\
\text { have to be followed, but it's happening the dear time, nearing completion. }\end{array}$ \\
\hline & & & $\begin{array}{l}\text { C2: we try to inject innovation, so for them to seek out SEBRAE again, it explained } \\
\text { that despite being a specific target job, they need to have other means of living [...] } \\
\text { (reporting on the seasonality of border communities in the state of Amazonas). }\end{array}$ \\
\hline & & & $\begin{array}{l}\text { C3: you have to find what we can contribute to certain company. Then you look by } \\
\text { segments, a tourist agency and asks: - How can I, as a consultant, help that entrepre- } \\
\text { neur, with something he'll buy the idea? }\end{array}$ \\
\hline
\end{tabular}


As reported by the consultants the search for consulting in tourism is still in its infancy. In their experience, this is due to two factors: the lack of consolidation of the tourism market towards a more organized market, and a lack of perceived value of the consulting professional. On the other hand, it was found that SEBRAE is structured to serves the business of Amazonas tourism market in a more specific way, whether in the search for professionals with knowledge and experience in tourism or a dissemination plan and more reliable monitoring on the area. Three weaknesses in the tour-ism market were identified by the consultants:

- The disorganization of the tourism market in the region;

- $\quad$ The failure to monitor projects by the public authorities, leading informal institutions and professionals to use their activities for other purposes;

- $\quad$ The need for a more defined tourism product for the state.

Regarding tourism consulting in Amazonas, we high-light some limitations, specifically in relation to specific knowledge of tourism, because even though a business venture, the consultants recognize the need for more specific job, as well as the need for more professionals trained in the area, a factor that may be affecting the demand for the services. Among these, we highlight the following:

- Lack of interest in investing in knowledge, as hiring a consultant, whether intermediate or not, first requires a willingness on the part of entrepreneurs to invest in knowledge that will help them manage their businesses;

- $\quad$ Lack of company specialization: businesses operating in the region's tourism market sometimes spread their activities too thinly across various segments of the market, lacking specificity in their offers;

- Stigma of the term "consultant": as a consequence of using the term in other functions related to sales, there is often incorrect understanding of what a consultant actually does.
- Lack of trained and skilled professionals with experience in consulting for the tourism market: resulting in professionals from other areas providing consulting services in tourism.

- $\quad$ SEBRAE-AM is currently taking steps to improve its consulting system, such as efforts to reactivate and re-structure the SEBRAEAM Tourism consulting division, which had been disabled.

\section{PRACTICAL IMPLICATIONS AND/OR THEORY}

This work involving theoretical implications is based on a theoretical framework that aims to contribute to scientific studies in the field of tourism consultancy and encourage further research on the topic, which has been little discussed.

The practical implications analyzed in this research were revealed by means of initial studies, where it was observed that the tourism consultancy offer in the State of Amazonas is incipient, SEBRAE being practically the only institution that provides this service, among its other activities. In practice, this study contributes to the structuring of the offer of new tourism ventures, as well as stimulating the emergence new professionals wishing to make career in tourism consultancy. It therefore presents in detail the steps to be developed in the craft of the consultant's profession, still little explored in the local market, based on the results presented in this pa-per.

By identifying existing weaknesses and gaps in the tourism consulting market in Amazonas, this research demonstrates, step-by-step the model applied by a national reference institution, making it an invaluable tool for society interested in deepening the theory and practice in the area of tourism consultancy.

\section{FINAL CONSIDERATIONS}

During this research, it was found that there was a limited number of studies and publications on the topic, which was one of the initial challenges to 
be overcome by the authors. However, despite the limited theoretical discussion available, it was possible to assemble a theoretical framework that culminated in a broad discussion on what constitutes consulting and how it should be done.

The empirical results of this case study, as revealed by the field research, showed that SEBRAE offers an efficient and complete consulting activity; it is open to the entry of new professionals (corporate) on a sporadic basis, through public tenders, for which the selection process has several stages. Candidates who are approved have the opportunity to acquire new knowledge relating to the standard of efficiency of the institution.

It was noted that the steps listed in the stages of the provision of consulting services coincide with those cited by the authors discussed here, ranging from identifying the company's needs to assessing service pro-vided, but as the consultation service is provided on a rotation basis, there is a predefined time period in which to complete the consulting, and in some cases, this limitation could undermine the quality of the service provided.

In the results for the actual local situation, it was observed that SEBRAE operates in a participatory way throughout the state, disseminating and promoting tourism in Amazonas, through two large projects: Riverside Entrepreneurship and Routing Plan for Route 174.

Concerning the benefits and limitations of tourism consulting, the research found that it offers various benefits, such as knowledge, marketing guidelines, and professional financial support.

From the perspective of SEBRAE consultants, the results for Amazonas tourist market show the need for better organization of activities, less informality, better quality of services and more innovations in products and tourism services.

Regarding tourism consultancy, the results show a certain lack of interest by the tourism entre- preneurs in hiring consulting services. Also, an important situation pointed out by professionals is about the tourist consultancy market to be a little worked in the region, leaving room for new professional performances who are now being replaced by other professionals from correlated fields.

It was noted that SEBRAE-AM fills a gap in the tourist market, and has been organizing itself to serve the sec-tor more efficiently, to increase the demand from tour-ism businesses in the region.

\section{References}

A. P., A. C., E. T., Spilker, M. J., Silva, M. P., \& Oliveira, M. N. (2011). Análise de Conteúdo de uma Entrevista Semi-Estruturada. Accessed on June 17, 2017, available at http://mpelearning.pbworks.com/f/ MICO.pdf

Alves, J. d. (2015). Consultoria empresarial como ferramenta estratégica de desenvolvimento em pequenas empresas. Simposio de excelência e gestão e tecnologia (pp. 1-15). Resende: Faculdades Dom Bosco.

Barreto, M. (2003). Manual de Iniciação ao Estudo do Turismo. São Paulo: Papirus.

Beni, M. C. (2008). Análise estrutural do Turismo. São Paulo: Edito-ra Senac.

Block, P. (1991). Consultoria: O desafio da liberdade, coragem, confiança, parceria e implementação de qualidade em todas as decisões. São Paulo: Makron.

Brasil, P. N. (17 de setembro de 2008). Lei 11.771. Brasil. Accessed in 2016, available at http:// www.planalto.gov.br/ccivil_03/_ato20072010/2008/lei/l11771.htm

Cooper, C., J. F., A. F., D. G., \& S. W. (2001). Turismo Princípios e Prática. Porto Alegre: Bookman. 
Crato, C. (2010). Qualidade: Condição de competitividade. Porto: Sociedade Portuguesa de Inovação.

de Almeida Jordão Garcia, M. M., \& Leal Junior, I. G. (2012). A comercialização no mercado de produtos turisticos: Um estudo de caso na costa leste - MS. Fonte: Faculdades integradas de três lagoas: https://is.gd/ kGfAYX

de Azambuja, V. A., A. d., \& Fortes, J. d. (2009). O mercado de consultoria turística em Florianópolis. Caderno Virtual de Turismo, pp. 1-8.

Degen, R. J. (2009). O empreendedor: empreender como opção de carreira. São Paulo: Pearson Universidades.

Dornelas, J. (2001). Empreendedorismo: Transformando Ideias Em Negócios. Rio de Janeiro: Elsevier

Gerhardt, T. E., \& Silveira, D. T. (2009). Métodos de Pesquisa. Porto Alegre: Editora da UFRGS.

Gil, A. C. (2012). Como Elaborar Projetos de Pesquisa. São Paulo: Editora Atlas.

Jesus, C. G., \& da Silva, D. R. (26 de julho de 2017). Economia e Turismo Vol 1. Fonte: cecierj: https:// canal.cecierj.edu.br/recurso/6454

L. C., \& E. G. (2005). Consultoria Empresarial. São Paulo: Saraiva.

Lessa, J. (1995). Qualidade competitiva no Brasil. Bahia: Casa da qualidade.

Marconi, M. d., \& Lakatos, E. M. (2003). Fundamentos de metodo-logia cientifica. São Paulo: Atlas.
Mendes, A. R. (2012). O que é património cultural. Olhão: Gente Singular. Fonte: Universidade do Algarve.

Moraes, S. S., \& Gondim, C. B. (2013). Estudo sobre a importância e a demanda por serviços de consultoria nas empresas hote-leiras de João Pessoa-PB. Applied Tourism - Internacional Journal of Applied Science and Technology in Tourism, Hos-pitality, Food and Beverage, 1-15.

Oliveira, D. D. (1996). Manual de consultoria empresarial. São Pau-lo: Atlas.

Petrocchi, M. (2004). Marketing para destinos turísticos. São Paulo: Editora Alínea.

Pimenta, M. (2013). Gestão de Pessoas em turismo: Sustentabilida-de, Qualidade e Comunicação. São Paulo: Editora Alínea.

Santos, C. R. (2005). A alimentação e seu lugar na história: os tem-pos da memória gustativa. História: Questões de debate, pp. 11-31. Accessed on August 5, 2016, available at http:// gastronomiacozinhacontemporanea.blogspot.com.br/2014/04/artigo-miscigenacaona-gastronomia-do.html

SEBRAE. (s.d.). Cadernos de Atrativos Turísticos. São Paulo: SEBRAE. Accessed on July 26 2017, available at http://www.bibliotecas.sebrae.com.br/chronus/ ARQUIVOS_CHRONUS/bds/bds.nsf/ f0c67377542f8745845f4c4f6ff6bf97/\$File/ SP_cadernodeatrativosturisticos2_16.pdf.pdf

SEBRAE. (s.d.). Quem somos? Fonte: SEBRAE: http:// www.sebrae.com.br/sites/PortalSebrae/ufs/am/ quem_somos?codUf=4.

Teixeira, G. C. (2012). Referenciais de consultoria SEBRAE. Brasília: SEBRAE. Accessed on June 14, 2017, available at http://www.bibliotecas.sebrae.com.br/ 
chronus/ARQUIVOS_CHRONUS/bds/bds.nsf/ C08A566FFBE7EE29832579CF0049C370/\$File/ NT000474F2.pdf

Terra, L. (s.d.). Consultoria! O que é e como usar? Accessed on June 14, 2017, available at http:// www.bibliotecas.sebrae.com.br/chronus/ ARQUIVOS_CHRONUS/bds/ bds.nsf/05459F13AD8217E5832577AB006E2381/ \$File/NT000447A2.pdf

Trindade da Silva, L. M., Freire Medeiros, C. A., \& Costa, B. K. (2009). Inovação nos empreendimentos turísticos: Uma análise das práticas na cadeia produtiva turística do muni-cípio de Tibau do Sul,. Revista Turismo, 230-247.

Trindade da Silva, L. M., Freire Medeiros, C. A., \& Costa, B. K. (2010). Cultura organizacional e qualidade dos serviços turísticos: um estudo em restaurantes de Natal/RN. Turis-mo: Visão e Ação, pp. 230-247.

Turismo, Ministerio do. (2010). Segmentação do turismo e o mer-cado. Acesso em 26 de Julho de 2017, avaialble at http://www.turismo.gov.br/sites/default/ turismo/o_ministerio/publicacoes/ downloads_publicacoes/

Segmentaxo_do_Mercado_Versxo_Final_IMPRESSxO_.pdf.

Turismo, Ministerio do. (s.d.). Turismo no Brasil: Panorama Geral, Avaliação da Competitividade e Propostas de Políticas Públi-cas para o Setor. Accessed on November 25, 2016, available at http:// www.turismo.gov.br/sites/default/turismo/ o ministerio/publicacoes/downloads publicacoes/ ORGANIZAXO_INDUSTRIAL_DO_TURISMO.pdf.

Vale, M. L. (2003). Modelo de Gestão Hoteleira para Meios de Hospedagem Ambiental e Ecológico. Manaus: UFRJ. 